\title{
인도네시아 원조공여국 원탁회의
}

아체 - 니아스 재건복구사업을 지원하는 원조공여 국 관계자들은 2005.5.17(화) 자카르타에서 개최된 인도네시아 원조공여국 원탁회의에 아체 · 니아스 재 건복구특별기구(BRR:The Rehabilitation and Reconstruction Agency for Ache and Nias)의 Kuntoro의장을 초청, 동 특별기구의 활동 진행사항 을 점검하고 공여국간 관련 정보 등을 교환함.

I . 아체 - 니아스 재건복구사업 추진 을 위한 $\mathrm{BRR}$ 활동사항 점검(동 특별기구 설립 후 2주간)
싱턴에서 회의 개최, 약 400 개 기업 대표자들과 정책입안자들을 대상으로 $\mathrm{BRR}$ 홍보활동 전개 및 지원 요청

약 150 개의 $\mathrm{NGO}$ 를 대상으로 $\mathrm{BRR}$ 활동계획 안내

\section{2. 다목적사업 승인(주요 공여국 및 국제기구들} 에 의한 기추진 사업 위주)

ㅁ적십자사가 추진하는 주택, 학교, 병원건립 및

Family grant 종합프로젝트(600백만불)

$\square \mathrm{ADB}$ 주택지원 프로젝트(75백만불)

ㅁ USAID 도로건설 프로젝트(245백만불)

ㅁ Intel의 통신 광역사업(30백만불)

ㅁAO의 트랙터 545 대 지원

\section{1. 대외활동 전개}

마첵 - 니아스섬 피해지역을 방문, 정부관계자, 사 회지도자, 수혜자들과의 연석회의를 갖고 재건복 구방안 협의

마체에 대한 민간부문의 지원확대를 위해 미국 워

\section{3. 재건복구 지연 사항 해소}

ㅁㅁㄷㄷ단항에 5 개월 동안 적채되어 있던 1,500 개 긴급 구호용 지원물품 수송용 컨테이너 해소 ㅁ해상운송 및 보급지원 계획수립을 위한 계약업체 
선정(UNJLC)

아체 지역 활동 NGO 관계자들의 비자 연장 조치 (30일)

\section{4. 향후 추진계획}

60 일내 $\mathrm{BRR}$ 조직 구축 : 현재는 분야별 간부 임명 ㅁ 공여국과의 지속적인 업무협조로 재건복구사업의 가속화

- 공여국별 지원사업 현황자료 지속 보완 요청

\section{5. $\mathrm{BRR}$ 의 조직 정상화를 위한 공여국 지원사항}

ㅁ UNHCR : 사무실 건물 제공(임시 사용용)

AusAID : 중요 긴급사안에 대한 기술 및 자금지 원, 통신 및 홍보망 구축 자금지원, 컴퓨터 등 사무 장비 일체, 차량 및 기본시설 제공 등

USAID : 동 기구 인력 확보를 위한 인건비 및 운 영자금 15 백만불 지원

\section{II. 관찰 및 검토의견}

ㅁ BRR은 조직 구축과 병행하여 기존 진행중인 사업 을 재분류하고 사업승인 등 필요조치를 취하고 있 으나, BRR과 타 정부부처간의 업무이관과 협조가 정상적으로 이루어지지 않고 있음을 공여국들이 지적

BRR Kuntoro 의장은 아체의 경우 대부분 피해지 역이 초토화되어 모든 생활 시설을 종합적으로 구 축해야 하는 바, 가급적 공여국들이 주택 및 도로 건설, 학교와 병원 등 기간시설을 패키지로 지원할 수 있기를 희망한다고 언급

ㅁ 우리나라 정부가 제안한 10 개의 프로젝트는 학교, 병원 등 시설물 건축과 기타 크고 작은 여러 가지 분야의 소규모사업으로 구성되어 있을 뿐만 아니 라 향후 3 개년에 걸쳐 지원할 계획이므로 사업계 획 협의 및 구체화에 다소 시일이 소요될 것으로 예상됨.

[자료:주인도네시아 대사관] 